\title{
ENERGY EFFICIENCY AND MANAGEMENT ASSESSMENT OF A FOOD PROCESSING INDUSTRY: A STUDY OF A DAIRY INDUSTRY, NIGERIA
}

\author{
Sefiu Olawale ALABI ${ }^{1}$ and Prof. Chukuemeka J. DIJI ${ }^{2}$ \\ ${ }^{1}$ Maritime and Logistic Management Department, Australia Maritime College, University of \\ Tasmania, Australia \\ ${ }^{2}$ Associate Prof. of Mechanical Engineering Deputy VC-Research, Innovation Consultancy \& \\ Extension, Kampala International University, Kampala Uganda
}

DOI: 10.46609/IJSSER.2021.v06i01.001 URL: https://doi.org/10.46609/IJSSER.2021.v06i01.001

\begin{abstract}
The importance of energy for the creation of wealth and enhancing the global socio-economic growth cannot be overemphasized. Therefore, the recent incessant increase in the energy cost has necessitated the need to research into the efficient management and utilization of the available energy. In view of this, this study investigates the energy efficiency and management of a food processing in a multi-national dairy company, Fan Milk Plc, located in Ibadan, Oyo State, Nigeria. The study utilizes the energy intensity of production, energy cost of production and cost benefit analysis methodology to ascertain the efficiency of energy use. An audit and analysis were made for energy consumption in the company for a period of five years between 2011 to 2015 and this revealed energy efficiency gap as a result of poorly implemented energy management measures. The study revealed that energy is not efficiently used despite the company's reliance on self-generated power and the substantial increase in energy consumption in the third quarter of the year, between June and September for all the five years investigated, does not commensurate with the production increase. The research deduced that the unit cost of energy for production ranges from $\$ 9.58$ to $\$ 10.27$ with an energy intensity of $0.66 \mathrm{MJ}^{-1} \mathbf{t r}^{-1}$ and $0.7 \mathrm{MJltr}^{-1}$ respectively. Finally, the research recommends a thorough energy audit in the third quarter of each year which revealed considerably high energy intensity without commensurate increase in production.
\end{abstract}

Keywords: Energy, Efficiency, Food processing, management, 


\section{International Journal of Social Science and Economic Research}

ISSN: $2455-8834$

Volume:06, Issue:01 "January 2021"

\section{Introduction}

The most vital and life-wire of any industrial sustainability is the steady supply of energy at reasonable price (Wang, 2014) . The use of energy covers every aspect of human endeavour but its management and efficient use in many of the industries remain a question that is yet to be well researched (Sola and Mota, 2020). The current energy productions in Nigeria are based majorly on fossil fuels which are no longer sustainable in the present global economy (Aderemi et al., 2009), and the continuous increase in the cost of these energies to run many of the industries impact the return on investment and reduced profitability (Aiyedun et al., 2008). Energy efficiency is the ratio between the output of performance and the input of energy (Aderemi et al., 2009), and it refers to the reduction of energy input for a given service, it does not mean that energy should be used but should be used in a manner that will minimize the amount of energy needed to provide services, and this is possible where practices and products are improve (Abila, 2014). Therefore, the price volatility of energy today often impact earnings (Kelchevskaya et al., 2020) but the challenges of keeping to high product quality while still reduce production costs can be met through adequate investment in energy management which could be in the purchase of energy efficient technologies and implementation of plant-wide energy management (Fadare et al., 2010). Obviously, efficient energy management offers tremendous benefits such as increase production, quality improvement and optimal process performance which consequently enhance profitability (Yaman, 2009).

Efficient energy management also form part of the organizational component of environmental management strategy as it lead to emissions reduction (Schulze et al., 2016) Hence, strategic energy management which monitors and control energy usage as well as its efficient practice that minimize the energy needed for efficient service delivery is desirable for industrial profitability and sustainability. The importance of energy in economic sustainability is a well-accepted fact as energy has been an essential integral of social life and indeed the industrial sustainer (Sambo et al., 2012). Over the centuries, various sources of energy have been used to meet basic essentials of life and fossil fuels provides the huge source of energy (Thollander et al., 2020) with hydroelectricity providing almost $16 \%$ while nuclear source of energy provides about $10 \%$ of the global power generation, and other source accounted for $2 \%$ of the energy used in the world (Aiyedun et al., 2008). The energy stored in molecules of carbohydrates, proteins and other similar substances enable us to breathe, move, grow, think, live, play and even sleeping requires energy. Notably, without energy there is nothing human could achieve (Amri, 2017) and this explained the reasons for economic sustainability and growth in those developed countries. If any country must tackle the problem of poverty in her country, the provision and efficient management of energy remains one of the key factors that must be considered (Omer, 2008). 


\section{International Journal of Social Science and Economic Research}

ISSN: $2455-8834$

Volume:06, Issue:01 "January 2021"

However, in spite of the countless importance of energy, the use and conversion of energy often resulted in waste and emission which constituted environmental hazard (Pham et al., 2015) and this environmental problem created by energy usage had led to the growing interest in sustainable development which can only be achieved through judicious use of resources, strategic policy implementation and improved technology (Lee et al., 2017).

Therefore, the judicious use of energy resources and technologies to enhance its efficiencies are discussed under the concept of energy efficiency and its management. As a response to the challenges related to energy use, industries around the world strive to reduce energy intensities through the use of efficient energy technologies and management practices (Abdelaziz et al., 2011), and these laudable practices have not only improved the environmental sustainability but also enhance economic benefit and create considerable social advantages (Bunse et al., 2011). Studies have shown that tremendous benefits are inherent in implementing measures at ensuring efficient usage and management of energy especially in developing countries (Oyedepo, 2013). Unfortunately, Nigeria is lagging behind from adopting energy efficiency and management practices that are needed for industrialization and as such greatly missing the benefit of economic development (Keho, 2016). Energy efficiency is a desirable alternative for proper utilization of energy since it can guarantee similar level of economic activities with less fuel and good return on investment for the industries (Steinberger et al., 2009). Noise reduction, improve process control and time saving are among many of the non-energy advantages of energy efficiency and management (Galitsky et al., 2003a). As Nigeria manufactures face an intensely competitive world business environment, they crave for opportunities to minimize cost of production without adversely affect product quality or quantity but the volatile nature of the Nigeria energy prices often negatively impact the predictable return on investment, as the increasing energy tariffs are driving up costs of production (Aiyedun et al., 2008).

\section{Literature Review}

Energy efficiency has become the key driver of sustainable development in many economies in the world (Yaman, 2009). The strive to maintain good quality products as well as reducing cost of production often met through investment in energy efficient technologies and adequate practices (Bunse et al., 2011). Process efficiency, increase production, quality improvement and cost saving are among the benefits of energy efficiency technologies. An energy management and efficiency program also offer a firm pillar for corporate greenhouse gas management strategies as well as method for working towards the organizational "triple bottom line" which focuses on economic, social and the environmental aspects of the business (Introna et al., 2014), in a nutshell, investing in energy efficiency is an efficient strategy in today's global business sustainability. Aiyedun et. al (2008) conducted a research on energy management using a range 


\section{International Journal of Social Science and Economic Research}

ISSN: $2455-8834$

Volume:06, Issue:01 "January 2021"

of 5yrs data to determine the energy consumption, productivity and efficient management of a food company. The outcome of the research revealed that energy is not efficiently utilized and that the years that recorded the least energy consumption does not commensurate with the least production recorded at that same year. The research found that a substantial saving is obvious when the production equipment and machines are well maintained as this would not only improve production efficiency but also prolong equipment life span. Aiyedun proffered the procurement of test equipment to enhance energy monitoring and energy audit as well as energy saving equipment as some of the solutions to promote efficient energy management.

In another research conducted by Wang (2008) it was revealed that energy recovery and conservation through waste from food processing are important solutions to reduce production costs, stabilize economic growth and strengthening sustainability in the food processing industry. The transient energy consumption during food processing such as homogenizing and pasteurizing employ the use of heat transfer and this remain an important factor for optimal operation and minimal energy consumption. In his research it was concluded that heat transfer calculations are essential in the selection of appropriate insulation material. According to Bunse et al (2011), pumps and fans are predominately used in the movement of liquid foods and processing media such as air, water in the food processing industries, and this made it critical to understand how to select the correct fan or pump to enhance efficient energy management.

According to Javied et. al (2015), the consequence of the continuous increase in energy cost often lead the companies to a more expensive products hence it has been confirm that energy efficiency is not only vital for business sustainability but also make a viable environmental (Javied et al., 2015). For instance, Javied established that prior to implementing energy management system in Germany, a German norm which gives policies and procedures to audit the company can be prepared for internationally know energy management standard. However, it was revealed that there are a lot of obstacles such as finance resources, employee awareness, and technical know-how that often hinder the implementation of energy management. Several work about strategic approach for energy saving for food processing industries have been proposed. For instance, Muller et al. (2007) proposed an energy management approach based on top-down and bottom-up strategy as it is however not possible to prefer one method of energy management than the other (Muller et al., 2007). In another study, it was indicate that a clear bottom strategy can be used to study heat pump systems for recovery waste in the food and drink of French industry (Seck et al., 2013).

In addition, the potential for study the low grade heat recovery in the food and drink of the UK industry was also researched and according to Biglia et al (2015) where a thermal model for multi-energy system for a dairy industry was developed and used to study and enhance the global 


\section{International Journal of Social Science and Economic Research}

ISSN: $2455-8834$

Volume:06, Issue:01 "January 2021"

performance of the energy management during summer season, the model was calibrated using data obtained through a monitoring installed system on the plant and the result shown that solar system integration is viable and sustainable from the perspective of profitability. Biglia however discovered that investment in this discovery could lead to high cost that is not likely compensated by energy saving resulted from reduction in energy requirement. Hence, the research revealed that heat recovery system is profitable as it reduces the quantity of energy needed by the gas heater in spite of any dissipated amount of energy in the cooling tower (Biglia et al., 2015). Therefore, the immediate step in any energy management is to create a strategic and focused energy management initiative that would identify and implement the programme across the organisation as well as ensure steady improvement.

\section{Strategy for Energy Efficiency and Management}

By redefining the process of energy management and implementation, an organisation is equipped with strategies for cost- effectiveness and profitability. Steady and continuous energy management improvement is brought about when a devoted and committed organizational energy management committee exists (Ransom et al., 2007). Hence, a strong energy management programme would create platform to provide procedures for managing energy usage throughout the entire organizational processes. It is therefore imperative that a sound energy management programme is vital for energy efficiency to attain full potential, and it is important that personnel throughout the organisation are involve in all aspect of the energy management programme to enhance its success. 


\section{Components of Strategic Energy Efficiency and Management}

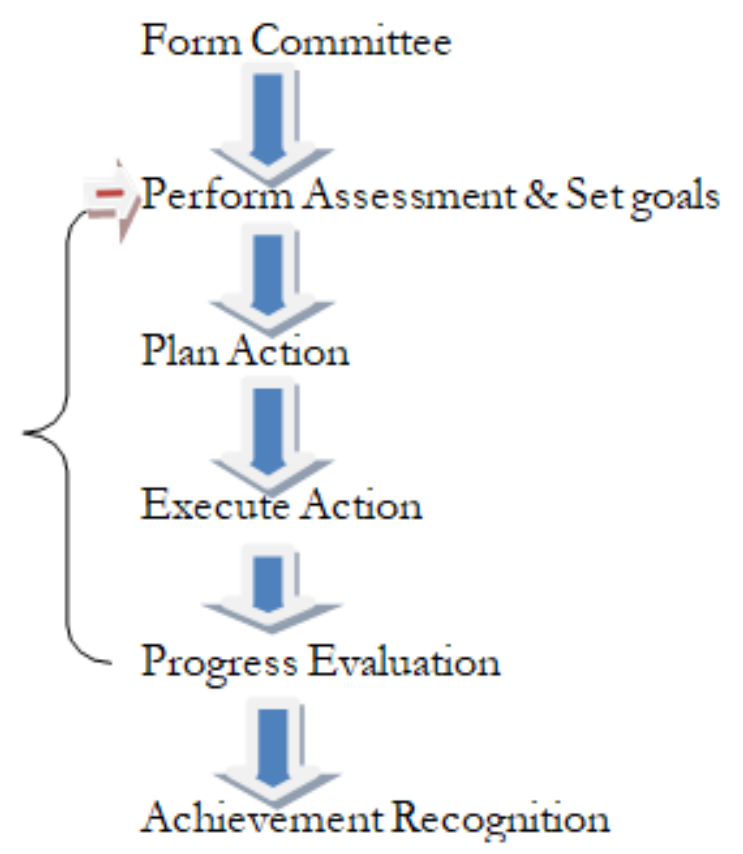

Fig: 1.0 Component of Strategic Energy Efficiency and Management Source: Author's design

The important step toward efficient energy management in an organisation begins with the establishment of energy committee (Wang et al., 2014). In addition, the conservation of energy in the manufacturing industries is of great importance; therefore, minimizing the cost of energy consumption is of immediate concern to Managers and Engineers in this sector of the economy. The cost of energy consumption which remains the prime factor of operation cost needs to be well monitored if operation and maintenance cost are to be reduced to an appreciable minimal (Javied et al., 2015). Hence, efficient utilization of energy in the manufacturing sector is hinged on an excellent performance of the machines and plant directly related to the production process, so, it is crucial to report the total consumption and the rate of energy usage for production equipments such as steam, water and air (Aiyedun et al., 2008). Hence, to fulfill this reduction and increase profitability of the company, the Energy Manager focuses his professional attention on the strategies to reduce energy consumption per production (Oyedepo, 2013).

The measurement of energy efficiency at the lowest level of aggregation, for instance a machine, is simple and straightforward. However, policy makers are generally interested in higher level of aggregation, e.g. energy efficiency of an industrial sector or a country. In this case, energy 
International Journal of Social Science and Economic Research

ISSN: 2455-8834

Volume:06, Issue:01 "January 2021"

efficiency cannot be directly measured and therefore has to be analyzed by the use of surrogative (indicators) measure (Yaman, 2009). Industrial energy efficiency can be measured in economic terms or physical terms, such as weight of products, number of output as related to cost of energy source, technological efficiency and labour etc. However, the energy efficiency of economic product cannot be precisely evaluated because it is a comprehensive operation, so, the energy efficiency indicator of industries is a ratio of operational output to energy input and this is a great concern to the industries (Oyedepo, 2013)

\section{Energy Efficiency Indicator}

An Energy efficiency indicators are divided into four main group and must be easily observable with little or no lag which relates to the target and goal variables (De Lombaerde and Van Langenhove, 2006).

i). The Thermodynamic Indicators: This indicator displays second law of efficiency and depends on the methods that can be used for the estimation of the actual energy used in the production process, and remains the most traditional system of evaluating energy efficiency through the process of scientific reaction (Tanaka, 2008). This first-law of energy efficiency was firstly used in micro-level energy efficiency process because it treats different energy inputs as the same measure units of heat content and measured in terms of change values of enthalpy $(\Delta \mathrm{H})$.

$$
E \Delta H=\frac{\Delta \text { Houtput }}{\Delta \text { HInput }}
$$

Where $\Delta H$ is the enthalpy efficiency

$\Delta$ Houtput represents the total output in a process and

$\Delta$ Hinput represents the total energy inputs in a process. The idea second law energy efficiency was adopted to expatiate on the application of heat transfer

$$
\text { where } p=\frac{E \Delta H(\text { actual })}{E \Delta H(\text { ideal })}
$$

P stands for the second-law efficiency of a process,

$\mathrm{E} \Delta \mathrm{H}$ actual is the actual enthalpy efficiency of a process and

$\mathrm{E} \Delta \mathrm{H}$ ideal is the ideal enthalpy of efficiency of a perfect manufacturing process.

ii). Thermo-physical Indicators: These are improved indicators where the numerator is the 
International Journal of Social Science and Economic Research

ISSN: 2455-8834

Volume:06, Issue:01 "January 2021"

thermal units and the denominator is estimated in physical units. It explains the quantity of energy required for production of each unit of product (Li and Tao, 2017).

iii). Thermo-economic indicators: This measure the change in secondary energy consumption as a result of energy intensity difference between the computation year and the base year (Li and Tao, 2017), and can be represented as

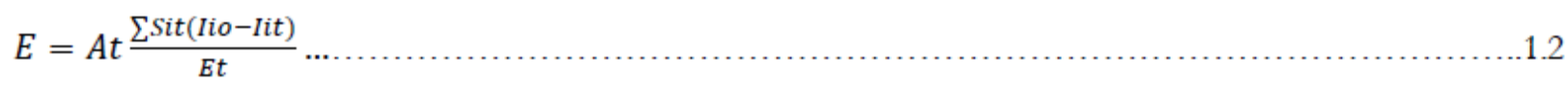

where

At represents the net output of activities, (the actual GDP), in a certain year.

Sit means share of output i,

Iit represents economic energy intensity of output I in the certain year.

Iio is the economic output I in the base year

$\boldsymbol{E} \boldsymbol{t}$ is the energy consumption in the certain year.

iv). The Economic Indicators: These represent the total dollar output of the sector, that is input and output are enumerated in monetary terms(Muller et al., 2007) and economic indicators are used as benchmark for various studies. In the early 1970s and 1980s, the comparisons are often between primary energy consumption and the real GDP. Scholars such as Turvey and Norbay, 1965 and Bullard and Herendeen 1967 are of the opinion that both input and output should be measured in reference to currency value, and they argued that energy price is better adopted than the thermodynamic units for the energy inputs ( $\mathrm{Li}$ and Tao, 2017). The energy intensity and other efficiency related factors often affect the changes of energy efficiency (Fadare et al., 2010) and the indicators explained earlier especially the thermodynamic indicators are adopted mostly at the device level and particular analysis such as boiler, turbine. The industrial energy efficiency is most popularly evaluated using the thermo- economic indicator and these measurement indicators are used at different estimation situations, hence, it is important to look into all similar factors that are essential in building a comprehensive system of energy efficiency measurement (Aiyedun et al., 2008). However, there are general consensus that energy efficiency indicator should relates, by means of a ratio, the amount of energy use to the useful output or activity (Oyedepo, 2013).

\section{Methods of Effective Energy Management}

There are various methods for assessing effective energy management and these methods 


\section{International Journal of Social Science and Economic Research}

ISSN: $2455-8834$

Volume:06, Issue:01 "January 2021"

includes efficient utilization of available energy resources, conservation of energy, technology development for recovery of waste energy, use of renewable energy systems, energy auditing and prevention of leakages (Aderemi et al., 2009).

\section{Typical Energy management Steps}

i) Metering energy consumption and collecting the data.

ii) Finding opportunities to save energy and estimating how much energy each opportunity could save, and could typically analyze meter data to find and quantify routine energy waste, and might also investigate the energy savings by replacing equipment (e.g. lighting) or by upgrading building's insulation.

Energy Audit: Historical data for facility is collected, reviewed and analyze. The review identify gross energy uses by fuel types, cyclic trends, fiscal year effects, dependence on sales or work load, and minimum energy-use ratios (Aderemi et al., 2009). Historical data assist in planning a detailed energy audit and alert the auditors as to the type of fuel and general equipment to expect. A brief facility walk-through is recommended to establish the plant layout, major energy uses and primary processes or functions of the facility. In some manufacturing and process industries it is of interest to determine the energy content of a product and this can be done by a variation of the energy audit techniques (Fadare et al., 2010). Since this approach resembles classical financial accounting, it is sometimes called energy accounting. In this procedure, the energy content of the raw materials is determined in a consistent set of energy units. Then, the energy required for conversion to a product is accounted for in the same units and the same is done for energy in the waste streams and the by-products. Finally, the net energy content per unit produced is used as a basis for establishing efficient goals (Sambo et al., 2012). Previous research on energy efficiency and management show that Corn wet milling in the United State is one of the most energy intensive industries within the food industries as its uses $25 \%$ of the energy in the entire food industry (Galitsky et al., 2003b). A typical corn wet milling plant in the United States spends approximately \$20 to \$30 million per year on energy, making energy efficiency improvement an important way to reduce costs and increase predictable earnings, especially in times of high energy-price volatility (Kluczek and Olszewski, 2017) .

\section{Overview of the Dairy Industry}

In the dairy industry, temperature (heat or cold) has an important influence on food processing because it is the most convenient way of extending the shelf life of foods. Indeed, either heat or cold destroys enzymatic and microbiological activity or removes water to inhibit deterioration (Aiyedun et al., 2008). Some of the various processes in the dairy industry are in the four categories below: 
i) Processing at ambient temperature

* Raw material preparation (cleaning, sorting, grading and peeling)

* Size reduction

* Mixing and forming

* Separation and concentration of food components

* Fermentation and enzyme technology

* Irradiation

* Processing using electric fields, high hydrostatic pressure, light or ultrasound

ii) Processing by application of heat

Heat processing using steam or water

* Blanching

* Pasteurization

* Heat sterilization

* Evaporation and distillation

* Extrusion

Heat processing using hot air

* Dehydration

* Baking and roasting

Heat processing using hot oils

* Frying

Heat processing by direct and radiated energy

* Dielectric, ohmic and infrared heating

iii) Processing by the removal of heat

* Chilling

* Controlled- or modified-atmosphere storage packaging

* Freezing

* Freeze drying (lyophilisation) and freeze concentration

iv) Post-processing operation

* Coating and enrobing

* Filling and sealing of containers

* Materials handling, storage and distribution

Source: Dairy Processing: Improving Quality (Smit, 2003)

Methodology 
International Journal of Social Science and Economic Research

ISSN: 2455-8834

Volume:06, Issue:01 "January 2021"

The dairy company under study has facilities such as homogenizer, pasteurizer, boiler, cooling fan, pump, conveyor belt, Tunnel freezer, scanima freezer, air purger, gram freezer which are all energy intense consuming equipment. The research uses data from 2011 to 2015 to make the period of five years and the data collections include details of monthly and annual records of diesel and electricity consumption for production processes, data for energy intensity, cost of energy for production and cost benefit ratio.

\section{Energy Intensity}

Energy Intensity is a measure of energy efficiency of the company and refers to the number of megawatt hour used to produce a liter of product.

$$
\text { Energy Intensity }(E I)=\frac{\text { Total Amount of Energy Used }}{\text { Total Production }}\left(\frac{\mathrm{J}}{\text { litres }}\right)
$$

\section{Cost of Production}

The Energy cost of Production is determine as the ratio of the cost of one unit of power (PHCN + Diesel) used per unit of product.

\section{Table 1: Total Production in Litre between 2011 and 2015}

\section{MONTH}

Jan
Feb
March
April
May
June
July

2011

$1,915,124.97$

$2,935,010.00$

$2,822,765.00$

$2,311,171.70$

$2,774,474.53$

$1,634,350.26$

$1,105,727.00$

\section{PRODUCTION (LITRES)}

2012

2013

2014

2015

$1,904,883.67$
$2,550,990.00$
$3,032,283.60$
$2,509,557.68$
$2,768,520.72$
$1,720,368.71$
$1,072,290.00$

$1,884,401.00$

$2,148,262.00$

$2,643,000.00$

$2,919,000.00$

$2,698,564.00$

$2,876,904.00$

$2,131,525.41$

$1,143,000.00$
$2,743,000.00$

$3,019,000.00$

$2,498,564.00$

2,976,904.00

$1,849,858.61$

$1,153,000.00$
$2,048,262.00$ 
International Journal of Social Science and Economic Research

ISSN: 2455-8834

Volume:06, Issue:01 "January 2021"

$\begin{array}{lrrrrr}\text { August } & 1,598,003.20 & 1,574,804.00 & 1,608,160.00 & 1,992,800.00 & 1,692,800.00 \\ \text { September } & 1,796,454.00 & 1,859,070.00 & 1,899,050.00 & 1,895,000.00 & 1,999,000.00 \\ \text { October } & 2,340,360.00 & 2,004,475.00 & 2,058,650.00 & 2,157,000.00 & 2,167,000.00 \\ \text { November } & 3,224,380.50 & 3,026,831.25 & 3,108,637.50 & 3,371,250.00 & 3,272,250.00 \\ \text { December } & 3,314,008.50 & 3,473,426.00 & 3,563,450.00 & 3,051,000.00 & 3,751,000.00 \\ \text { TOTAL } & 27,771,829.66 & 27,497,500.63 & 27,650,658.97 & 29,027,305.41 & 29,170,638.61\end{array}$

Source: Author's Collection

Energy Cost of Production $(E C P)=\frac{\text { PHCN Cost }+ \text { Diesel Cost }}{\text { Total Production }} \ldots \ldots \ldots \ldots$

\section{Benefit - Cost Analysis}

This compares the company's annual revenue made when electricity were purchased from the public supply (PHCN) as against the self generation. The benefit cost analysis is known as incremental analysis which compares the benefit cost ratio of two different years to determine the performance and where improvement is required.

The Incremental ratio is expressed below

$$
\text { Incremental Benefit }- \text { Cost Ratio }=\frac{\text { B of preceding year }-B \text { actual year }}{C \text { of preceding vear }- \text { C of actual vear }}=\frac{\Delta B}{\Delta c} \ldots \ldots \ldots \ldots 1.5
$$

Where,

$\mathrm{B}=$ Energy Cost from $\mathrm{PHCN}$

$\mathrm{C}=$ Energy Cost from self generation using diesel including cost of maintain the cost of generators . 
International Journal of Social Science and Economic Research

ISSN: 2455-8834

Volume:06, Issue:01 "January 2021"

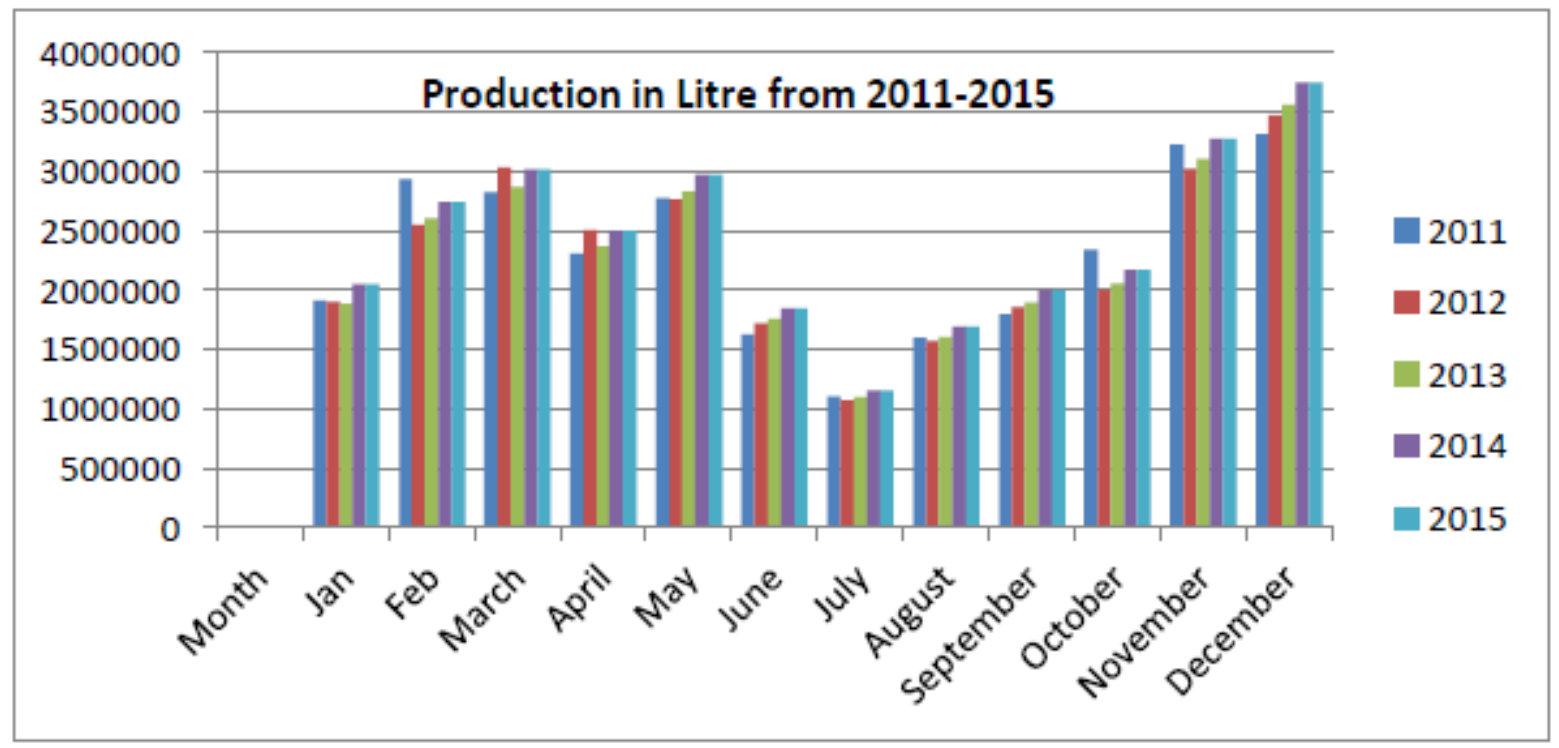

Figure 1.1 Graphical Representation of Production from 2011-2015 Source: Author's Design

Table 2: Fossil Fuel (Diesel) for self Power Generation from 2011-2015

MONTH

$\begin{array}{lccccc} & 2011 & 2012 & 2013 & 2014 & 2015 \\ \text { Jan } & 110,760 & 106,750 & 97,615 & 105,190.75 & 111,905 \\ \text { Feb } & 125,008 & 141,542 & 151,001 & 161,216.45 & 147,905 \\ \text { March } & 98,007 & 99,975 & 101,324 & 106,933 & 114,982 \\ \text { April } & 96,750 & 90,450 & 91,842 & 109,821 & 104,096 \\ \text { May } & 113,970 & 109,750 & 121,659 & 144,596 & 158,029 \\ \text { June } & 114,790 & 105,500 & 113,501 & 124,535.73 & 132,909 \\ \text { July } & 92,741 & 90,115 & 82,745 & 80,783.87 & 86,584 \\ \text { Angust } & 97,741 & 95,510 & 97,250 & 98,336 & 93,654 \\ \text { September } & 88,792 & 101,380 & 91,370 & 89,037 & 94,721 \\ \text { October } & 119,870 & 114,419 & 116,350 & 126,664 & 134,749 \\ \text { November } & 114,201 & 102,778 & 97,226 & 110,225 & 104,977 \\ \text { December } & 109,751 & 119,008 & 124,071 & 136,035 & 144,719 \\ \text { TOTAL } & 1,282,381 & \mathbf{1 , 2 7 7 , 1 7 7} & \mathbf{1 , 2 8 5 , 5 0 4} & \mathbf{1 , 3 9 3 , 3 7 3 . 7 5} & \mathbf{1 , 4 2 9 , 4 2 3}\end{array}$

Source: Author's collection 
International Journal of Social Science and Economic Research

ISSN: 2455-8834

Volume:06, Issue:01 "January 2021"

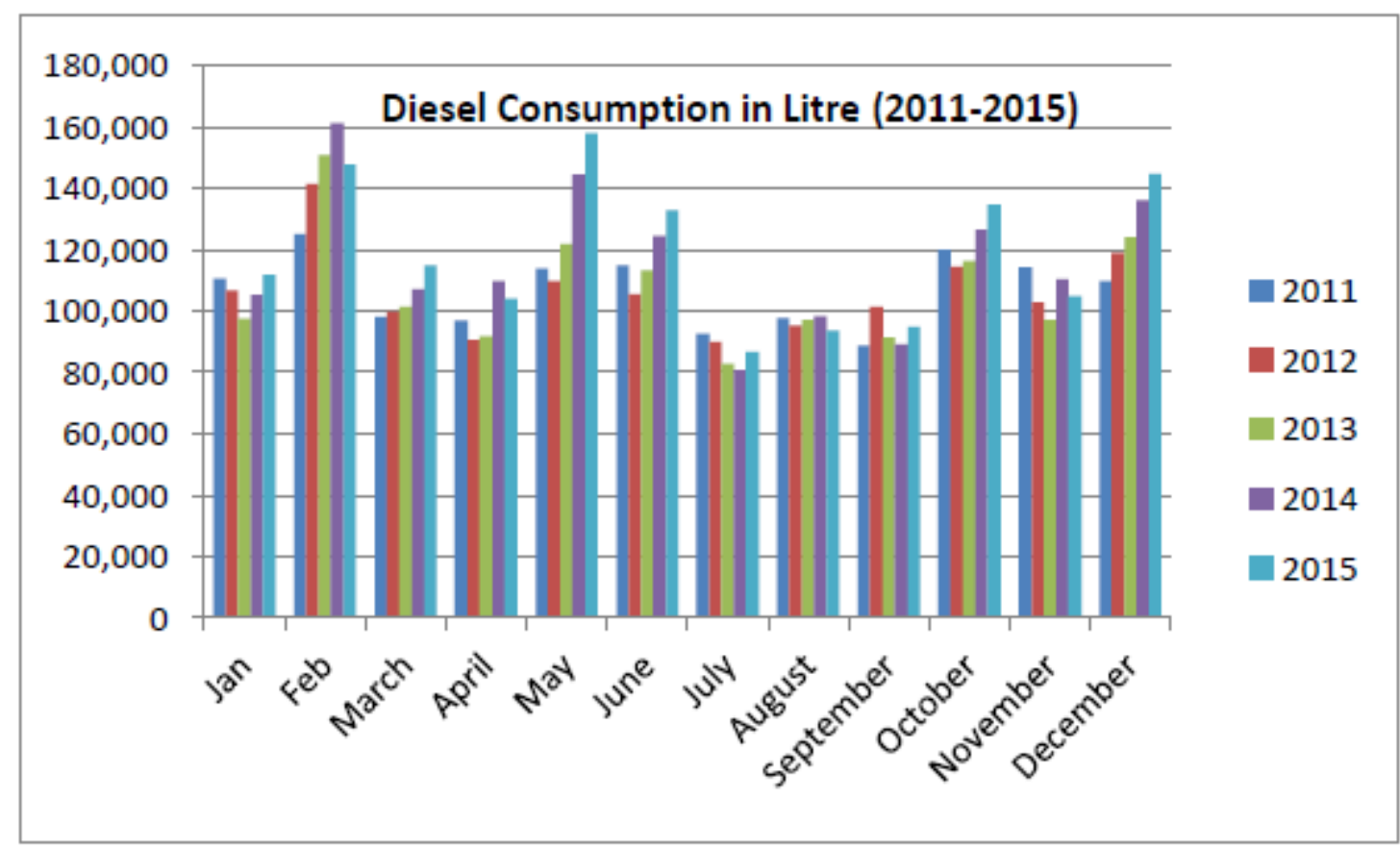

Figure:1.2 Trend of Fossil Fuel (Diesel) for self Power Generation from 2011-2015 Source: Author's Design

The table below also contained the power consumption from the public supply (PHCN) between 2011 and 2015.

Table 3: Power Consumption from Public Supply-PHCN (2011-2015)

\begin{tabular}{lccccc} 
MONTH & \multicolumn{5}{c}{ POWER CONSUMPTION FROM PHCN (kWh) } \\
& 2011 & 2012 & 2013 & 2014 & 2015 \\
Jan & $265,217.00$ & $289,765.00$ & $275,283.00$ & $285,635.00$ & $294,740.00$ \\
Feb & $285,121.00$ & $271,521.00$ & $298,367.00$ & $316,234.00$ & $339,310.00$ \\
March & $400,821.00$ & $465,148.00$ & $487,425.00$ & $503,423.00$ & $508,010.00$ \\
April & $434,652.00$ & $456,142.00$ & $428,902.00$ & $463,450.00$ & $470,750.00$ \\
May & $372,456.00$ & $365,246.00$ & $357,213.00$ & $352,760.00$ & $343,330.00$ \\
June & $406,122.00$ & $407,182.00$ & $409,567.00$ & $413,760.00$ & $418,960.00$ \\
July & $408,234.00$ & $412,567.00$ & $434,210.00$ & $423,612.00$ & $446,020.00$ \\
August & $404,123.00$ & $444,365.00$ & $465,890.00$ & $474,821.00$ & $495,750.00$
\end{tabular}


International Journal of Social Science and Economic Research

ISSN: 2455-8834

Volume:06, Issue:01 "January 2021"

$\begin{array}{lrrrrr}\text { September } & 398,762.00 & 410,423.00 & 409,435.00 & 421,061.00 & 440,800.00 \\ \text { October } & 408,635.00 & 412,652.00 & 413,221.00 & 409,623.00 & 440,000.00 \\ \text { November } & 398,762.00 & 409,272.00 & 423,091.00 & 413,002.00 & 420,000.00 \\ \text { December } & 387,612.00 & 387,624.00 & 352,347.00 & 398,453.00 & 424,030.00 \\ \text { TOTAL } & 4,570,517.00 & 4,731,907.00 & 4,754,951.00 & 4,875,834.00 & 5,041,700.00 \\ \text { Source: Author's Design }\end{array}$

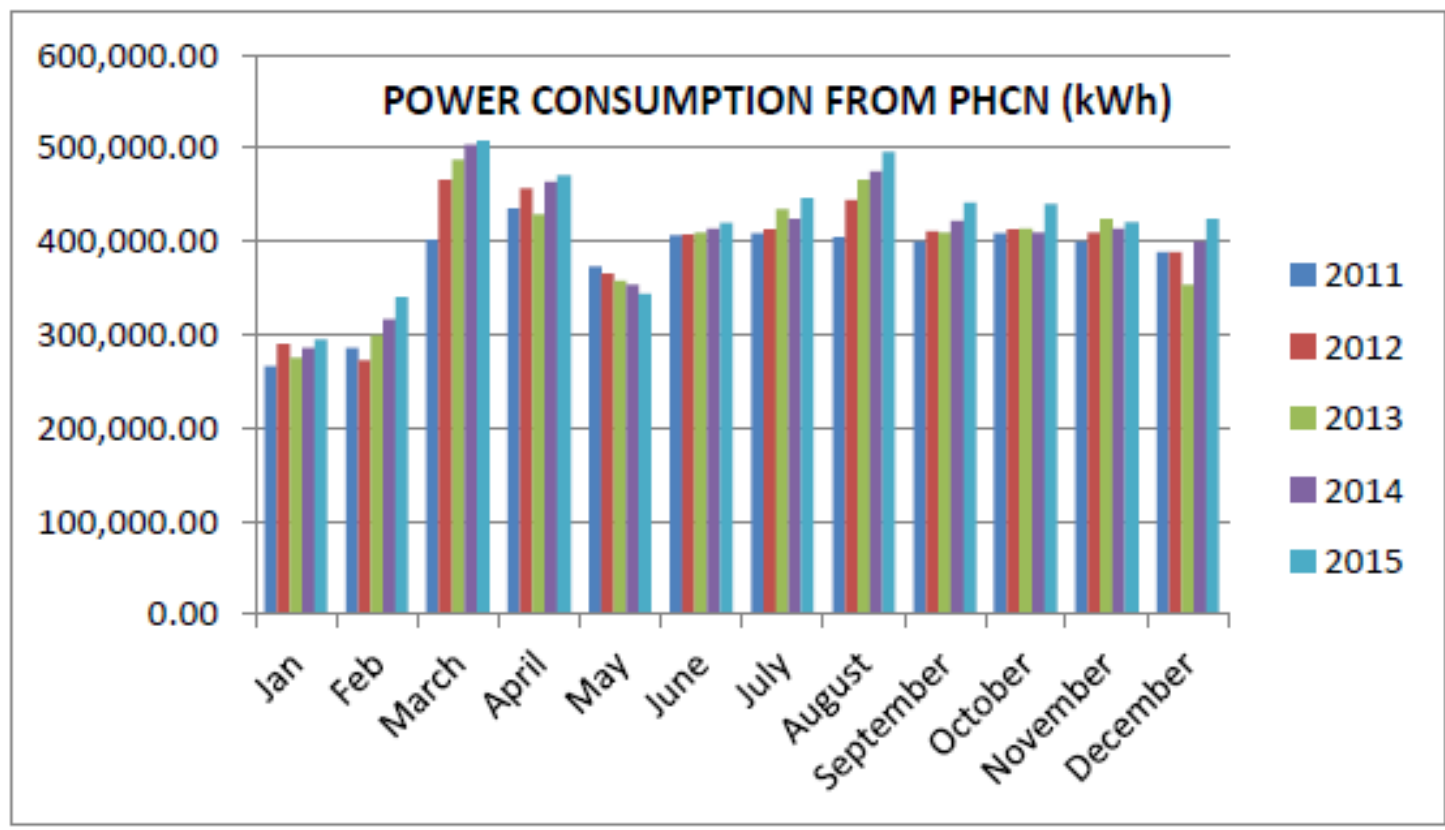

Fig:1.3 Trend of Public Power Consumption (2011-2015)

Source: Author's Design 
International Journal of Social Science and Economic Research

ISSN: 2455-8834

Volume:06, Issue:01 "January 2021"

Table 4: Comparison of Public Power Supply and Self Generated Source: Author's findings

\begin{tabular}{|c|c|c|c|c|c|}
\hline & \multicolumn{5}{|c|}{ YEAR } \\
\hline & 2011 & 2012 & 2013 & 2014 & 2015 \\
\hline $\begin{array}{l}\text { PHCN-Public } \\
\text { Supply(GJ) }\end{array}$ & 16453.86 & 17034.86 & 17117.82 & 17553 & 18150.12 \\
\hline $\begin{array}{l}\text { Self Generated } \\
\text { Power (GJ) }\end{array}$ & 52449.38 & 52236.54 & 52577.11 & 56988.99 & 58463.4 \\
\hline $\begin{array}{l}\text { Total Energy } \\
\text { (GJ) }\end{array}$ & 68903.24 & 69271.4 & 69694.93 & 74542 & 76613.52 \\
\hline $\begin{array}{l}\% \text { of (Public } \\
\text { Supply) PHCN }\end{array}$ & 23.9 & 24.6 & 24.6 & 23.5 & 23.7 \\
\hline $\begin{array}{l}\% \text { of Self } \\
\text { Generated } \\
\text { (Diesel) }\end{array}$ & 76.1 & 75.4 & 75.4 & 76.5 & 76.3 \\
\hline
\end{tabular}

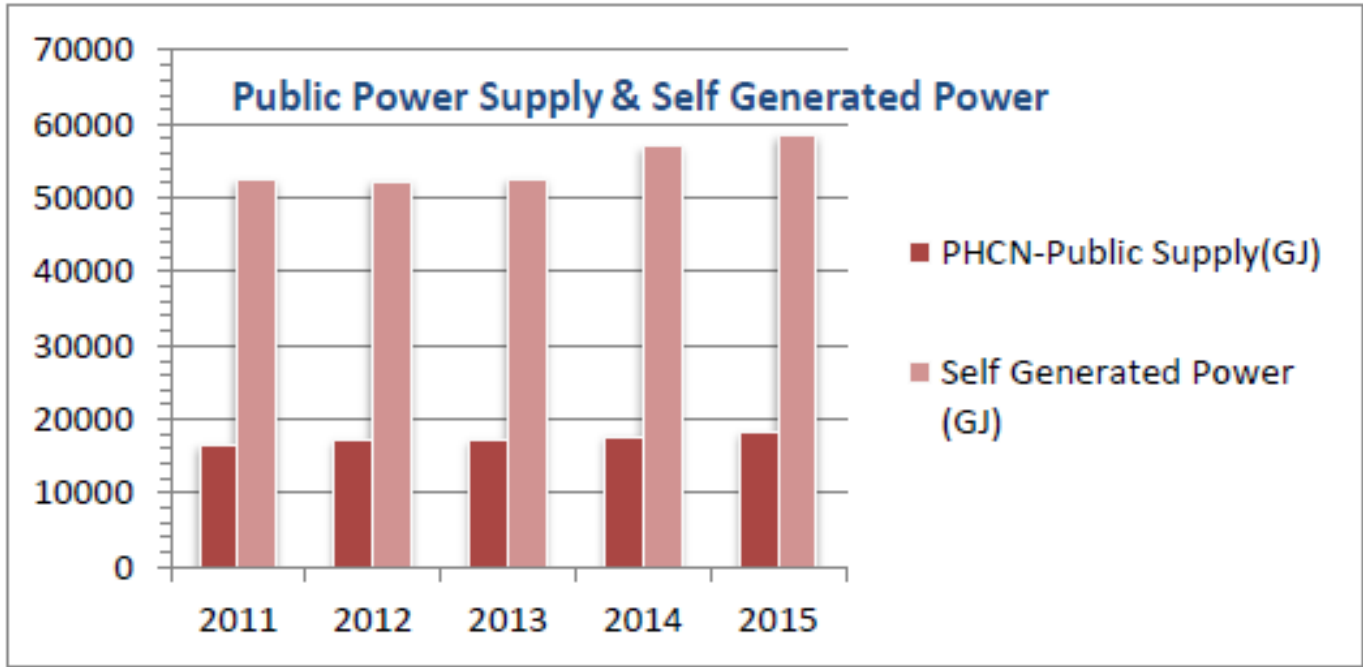

Fig: 1.4 Graphical Comparison of Public Power Supply and Self Generated Source: Author's Design

Note: I litre of (Refined Fuel) Diesel $=40.9 \mathrm{MJ} ; 1 \mathrm{kWh}$ of Electricity $=3.6 \mathrm{MJ}$

\section{Findings and Discussion}

From the table 1 above, there was an indicative total increase in production in 2015 while the year 2011 recorded the least output, and November of the year 2015 was when the organisation recorded the highest production output and the month of July, 2011 recorded the least output. From figure 1.2, the diesel consumption from the self generated power was highest in the year 
2015 while the lowest consumption was recorded in the year 2011. However, February of the year 2014 was the year with the highest consumption of diesel from self generation of power while in July of 2013 the consumption dropped by $50 \%$ as compared to July of the year 2014.

\section{Table:5 Energy Intensity of Production $(1 \mathrm{kwh}=3.6 \mathrm{MJ})$}

\begin{tabular}{lccccc}
\multicolumn{5}{c}{ Energy Intensity (MJ/litre) } & \\
& 2011 & 2012 & 2013 & 2014 & 2015 \\
Jan & 0.5 & 0.55 & 0.53 & 0.5 & 0.52 \\
Feb & 0.35 & 0.38 & 0.41 & 0.41 & 0.45 \\
March & 0.51 & 0.55 & 0.61 & 0.6 & 0.61 \\
April & 0.68 & 0.67 & 0.65 & 0.67 & 0.68 \\
May & 0.48 & 0.47 & 0.45 & 0.43 & 0.42 \\
June & 0.89 & 0.85 & 0.84 & 0.81 & 0.82 \\
July & 1.33 & 1.4 & 1.43 & 1.3 & 1.4 \\
August & 0.91 & 1.02 & 1.04 & 1 & 1.1 \\
September & 0.8 & 0.8 & 0.8 & 0.76 & 0.79 \\
October & 0.63 & 0.74 & 0.72 & 0.68 & 0.73 \\
November & 0.44 & 0.5 & 0.5 & 0.45 & 0.46 \\
December & 0.42 & 0.4 & 0.36 & 0.38 & 0.41 \\
AVERAGE & 0.66 & 0.694 & 0.635 & 0.666 & 0.7
\end{tabular}

Source: Author's Design 
International Journal of Social Science and Economic Research

ISSN: 2455-8834

Volume:06, Issue:01 "January 2021"

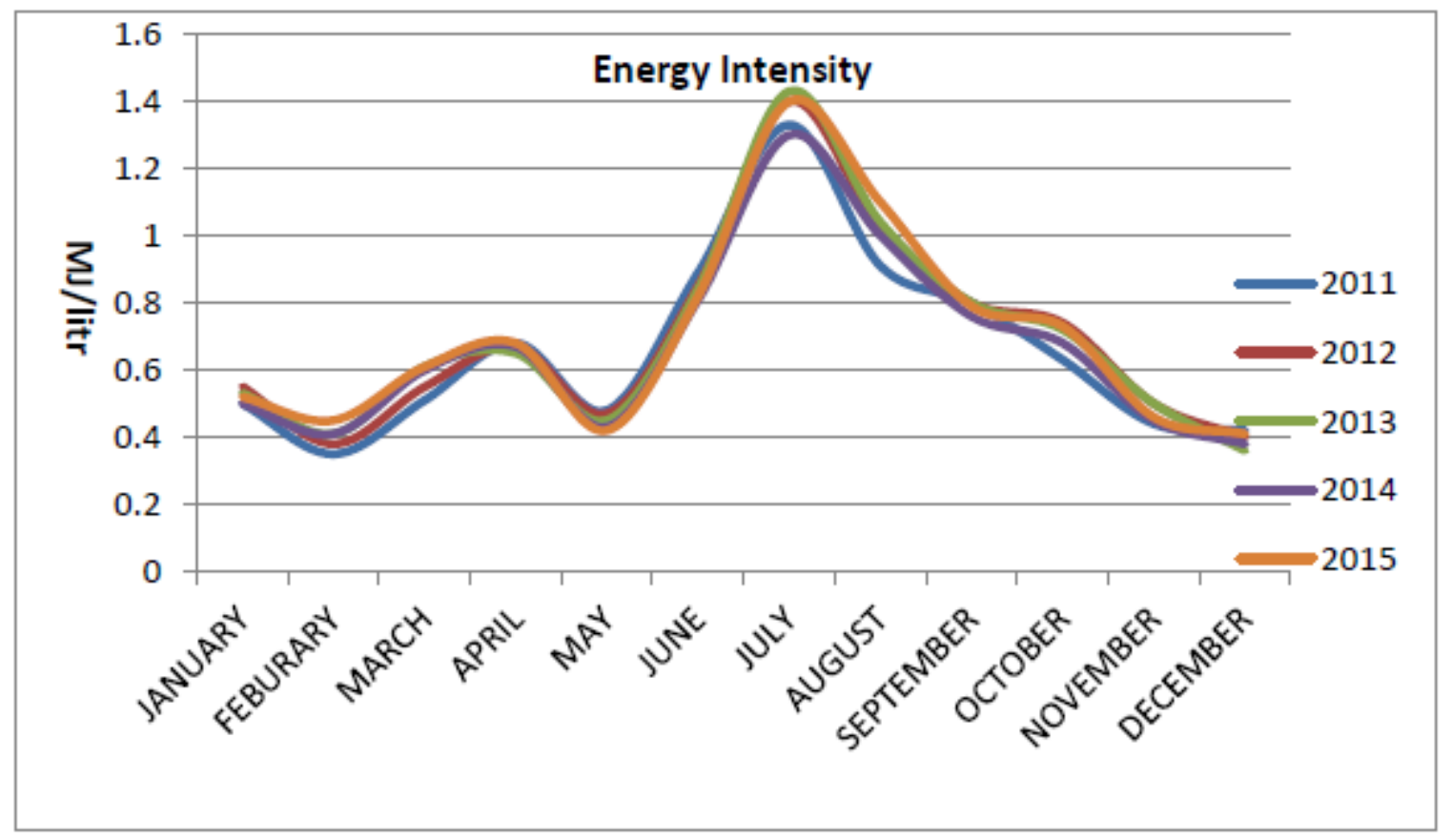

Figure:1.5 Trend in the Energy Intensity (2011-2015)

Source: Author's Design.

\section{Energy Intensity of Production}

The energy intensity of production measured in MJ/litre is as shown in the Table 5 above while Figure 1.5 shows the trend of the energy distribution across the period under consideration. Energy intensity of production is the unit amount of energy used for producing a unit of the company's product, and considering the trend in the intensity of the energy between June and September of each year under review, it became worrisome because the energy intensity almost doubled and do not commensurate the production output, and this calls for immediate audit of the energy activities especially during this identified period. 
International Journal of Social Science and Economic Research

ISSN: 2455-8834

Volume:06, Issue:01 "January 2021"

Table: 6 Total Cost of Energy

$\begin{array}{ccccr}\begin{array}{c}\text { Public Power } \\ \text { Consumption } \\ \text { (N) }\end{array} & \begin{array}{c}\text { Self } \\ \text { Generated } \\ \text { Power (N) }\end{array} & \begin{array}{c}\text { Total Cost } \\ \text { of Power } \\ \text { for } \\ \text { Production } \\ \text { (N) }\end{array} & \begin{array}{c}\text { Total } \\ \text { Production } \\ \text { (Ltr) }\end{array} & \begin{array}{c}\text { Energy Cost } \\ \text { of } \\ \text { Production } \\ \text { (N)/Litres) }\end{array} \\ & & & & \\ 66,647,220 & 181,158,149 & 247,805,369 & 25,856,705 & 9.58 \\ 68,822,399 & 184,475,823 & 253,298,222 & 27,497,501 & 9.21 \\ 72,123,920 & 188,126,791 & 260,250,711 & 27,650,659 & 9.41 \\ 81,718,474 & 201,185,867 & 282,904,341 & 29,027,305 & 9.75 \\ 81,281,156 & 218,292,763 & 299,573,919 & 29,170,639 & 10.27\end{array}$

\section{Source: Author's Design}

\section{Cost Benefit Ratio}

From equation 1.5 above, the cost benefit ratio is calculated for each year. Year 2011 remain zero since there was no energy cost estimation for the preceding year 2010. However, year 2012, 2013, 2014 and 2015 are calculated thus;

$$
\begin{aligned}
& \text { Incremental Benefit }- \text { Cost Ratio, Year } \mathbf{2 0 1 2}=\frac{66,647,220-68,822,399}{181,158,149-184,475,823}=0.66 \\
& \text { Incremental Benefit }- \text { Cost Ratio, Year } \mathbf{2 0 1 3}=\frac{68,822,399-72,123,920}{184,475,823-188,126,791}=0.91 \\
& \text { Incremental Benefit }- \text { Cost Ratio, Year } \mathbf{2 0 1 4}=\frac{72,123,920-81,718,450}{188,126,791-201,185,867}=0.73 \\
& \text { Incremental Benefit }- \text { Cost Ratio, Year } \mathbf{2 0 1 5}=\frac{81,718,450-81,281,156}{201,185,867-218,292,763}=0.026
\end{aligned}
$$


International Journal of Social Science and Economic Research

ISSN: 2455-8834

Volume:06, Issue:01 "January 2021"

\section{Table: 7 Cost Benefit Ratio}

\begin{tabular}{|c|c|c|c|c|c|}
\hline \multicolumn{5}{|c|}{ Quantity of Litres Produced with Self Power Generated against Public Power } & $\begin{array}{l}\text { Cost } \\
\text { Benefit } \\
\text { Ratio }\end{array}$ \\
\hline \multicolumn{3}{|c|}{ Estimate from Public Power Supply } & \multicolumn{2}{|c|}{ Estimate from Self Power Generation } & \\
\hline & Production (ltrs) & Cost of Power (N) & Production (ltrs) & Cost of Power (N) & \\
\hline 2011 & $6,954,157.18$ & $66,647,220.00$ & $18,302,547.51$ & $181,158,149.00$ & 0 \\
\hline 2012 & $7,468,260.61$ & $68,822,399.00$ & $20,018,388.52$ & $184,475,823.00$ & 0.66 \\
\hline 2013 & $7,662,895.17$ & $72,123,920.00$ & $19,987,763.80$ & $188,126,791.00$ & 0.9 \\
\hline 2014 & $8,384,696.34$ & $81,718,450.00$ & $20,642,608.00$ & $201,185,867.00$ & 0.73 \\
\hline 2015 & $7,914,709.60$ & $81,281,156.00$ & $21,255,985.00$ & $218,292,763.00$ & 0.026 \\
\hline
\end{tabular}

\section{Source: Author's Design}

\section{Conclusion}

The incremental cost benefit methodology is aimed at estimating the margin by which a public power supply or self power generation is more beneficial or costly. The method involved enumerating the least costly to the most expensive and compares the least cost with the cheapest by subtracting the total discounted benefits from each and divides by the total discounted cost of each project. This method systematically quantified all viable expenses and exposes strength, weaknesses and benefits of both power supplied to the company from PHCN and the self generated power to determine which might be profitable to the organisation. Hence, it provides advantage for management to evaluate qualitative arguments through the quantitative data from this analysis. From the table 6 above, it can be seen that the cost of producing one unit of product in 2012 was lower compared to the highest cost recorded in the year 2015 however the volume of production recorded in the year 2014 and 2015 were almost similar but still had different unit cost of energy of production and this was as a result of high input recorded from self power generation in the years 2015 which were not commensurate to production volume. Hence, for the company to keep down her energy cost per unit of product, it is imperative to bring down the energy cost through the reduction of fossil fuel (Diesel) for self generated power or keep the same level of consumption but investigate into how production profile could be enhanced through proper energy audit of the company.

From Table 7, we can deduced that the company derived benefits from using the public power supply to support its production activities between 2011 through to 2015 when the benefits appeared disapearing and this obviously calls for audit of the production activities to plug all identifiable loop holes in the system. In conclusion, the study discovered that over $75 \%$ of the 
International Journal of Social Science and Economic Research

ISSN: 2455-8834

Volume:06, Issue:01 "January 2021"

energy utilized in the factory were from self generation with average energy intensity of 0.66 to $7.0 \mathrm{GJ} / \mathrm{ltr}$. The study also revealed that the average energy cost of production stood at average of N9.5 per litre and identified the third quarter of each year investigated, from June to September, as a period of high energy usage and wastage which required further energy audit to identify the cause of wastage during this period despite that the period does not coincides with high volumes of production.

\section{Recommendation}

The study recommends the following to improve the efficiency and management of the energy usage;

a) There is need for thorough energy audit and vigilance in the third quarter of the year as the rate of energy consumption is higher and not in any way constitute high profit margin.

b) The current over $75 \%$ of self generated power without commensuration with production volume and profit should be investigated.

c) The company should consider divesting from the use of diesel to natural gas as a better option considering the high cost of diesel.

d) Consideration should also be given to the employment of an energy manager that can help in reducing the energy usage by monitoring the way energy is use in production and across the organisation

e) Setting up of an energy management committee would as well go a long way in addressing the nonchalant attitude of the entire staff in the management and judicious use of power.

f) Adoption of energy saving machineries and equipment should be explored as part of the drivers of efficient power utilization and management in the organisation.

\section{Limitation}

This study is by no means exhaustive; therefore, a further work will be required to examine other means through which the company could be prone to wasting energy as well as look further into how the entire staff could better be sensitized to imbibe the culture of saving energy. Also, information and data for the analysis were limited to what was available at the time of this work and as such the research may inject element of uncertainty in cost benefit which is uncommon in decision making. 
International Journal of Social Science and Economic Research

ISSN: 2455-8834

Volume:06, Issue:01 "January 2021"

\section{References}

ABDELAZIZ, E., SAIDUR, R. \& MEKHILEF, S. 2011. A review on energy saving strategies in industrial sector. Renewable and sustainable energy reviews, 15, 150-168.

ABILA, N. 2014. Managing municipal wastes for energy generation in Nigeria. Renewable and Sustainable Energy Reviews, 37, 182- 190.

ADEREMI, A., ILORI, M., ADEREMI, H. \& AKINBAMI, J. 2009. Assessment of electrical energy use efficiency in Nigeria food industry. African Journal of Food Science, 3, 206-216. AIYEDUN, P., ADEYEMI, O. \& BOLAJI, B. O. 2008. Energy Efficiency of a Manufacturing Industry: A Case Study of Nigeria Eagle Flour Mills Limited Ibadan.

AMRI, F. 2017. Intercourse across economic growth, trade and renewable energy consumption in developing and developed countries. Renewable and Sustainable Energy Reviews, 69, 527534.

BIGLIA, A., FABRIZIO, E., FERRARA, M., GAY, P. \& AIMONINO, D. R. 2015. Performance assessment of a multi- energy system for a food industry. Energy Procedia, 82, 540-545.

BUNSE, K., VODICKA, M., SCHÖNSLEBEN, P., BRÜLHART, M. \& ERNST, F. O. 2011. Integrating energy efficiency performance in production management-gap analysis between industrial needs and scientific literature. Journal of Cleaner Production, 19, 667-679.

DE LOMBAERDE, P. \& VAN LANGENHOVE, L. 2006. Indicators of regional integration: conceptual and methodological aspects. Assessment and measurement of regional integration, $13,9$.

FADARE, D., BAMIRO, O. \& ONI, A. 2010. Energy and cost analysis of organic fertilizer production in Nigeria. Energy, 35, 332-340.

GALITSKY, C., MARTIN, N., WORRELL, E. \& LEHMAN, B. 2003a. Energy efficiency improvement and cost saving opportunities for breweries. University of California, Berkeley.

GALITSKY, C., WORRELL, E. \& RUTH, M. 2003b. Energy efficiency improvement and cost saving opportunities for the Corn Wet Milling Industry: An ENERGY STAR Guide for Energy and Plant Managers.

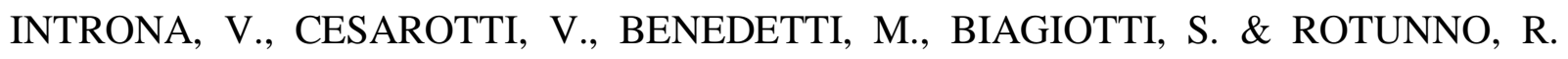
2014. Energy Management

Maturity Model: an organizational tool to foster the continuous reduction of energy consumption in companies. 
International Journal of Social Science and Economic Research

ISSN: 2455-8834

Volume:06, Issue:01 "January 2021"

Journal of cleaner production, 83, 108-117.

JAVIED, T., RACKOW, T. \& FRANKE, J. 2015. Implementing energy management system to increase energy efficiency in manufacturing companies. Procedia CIRP, 26, 156-161.

KEHO, Y. 2016. What drives energy consumption in developing countries? The experience of selected African countries. Energy Policy, 91, 233-246.

KELCHEVSKAYA, N., SHIRINKINA, E. \& ATLASOV, I. Assessing energy efficiency factors in industrial companies. IOP Conference Series: Materials Science and Engineering, 2020. IOP Publishing, 042001.

KLUCZEK, A. \& OLSZEWSKI, P. 2017. Energy audits in industrial processes. Journal of cleaner production, 142, 3437-3453. LEE, M., KELLER, A. A., CHIANG, P.-C., DEN, W., WANG, H., HOU, C.-H., WU, J., WANG, X. \& YAN, J. 2017.

Water-energy nexus for urban water systems: A comparative review on energy intensity and environmental impacts in relation to global water risks. Applied Energy, 205, 589-601.

LI, M.-J. \& TAO, W.-Q. 2017. Review of methodologies and polices for evaluation of energy efficiency in high energy- consuming industry. Applied Energy, 187, 203-215.

MULLER, D. C., MARECHAL, F. M., WOLEWINSKI, T. \& ROUX, P. J. 2007. An energy management method for the food industry. Applied Thermal Engineering, 27, 2677-2686.

OMER, A. M. 2008. Energy, environment and sustainable development. Renewable and sustainable energy reviews, 12, 2265-2300. OYEDEPO, S. O. 2013. Energy in perspective of sustainable development in Nigeria. Sustainable Energy, 1, 14-25.

PHAM, T. P. T., KAUSHIK, R., PARSHETTI, G. K., MAHMOOD, R. \& BALASUBRAMANIAN, R. 2015. Food waste-to-energy conversion technologies: Current status and future directions. Waste Management, 38, 399-408.

RANSOM, D. S., CHIVERS, D. A., FORTH, J. B., GILES, D. W., TEACHMAN, M. E., YEO, J. W. \& KI, C. S. S. 2007.System and method for securing energy management systems. Google Patents.

SAMBO, A. S., GARBA, B., ZARMA, I. H. \& GAJI, M. M. 2012. Electricity generation and the present challenges in the Nigerian power sector. Journal of Energy and Power Engineering, 6, 1050-1059.

SCHULZE, M., NEHLER, H., OTTOSSON, M. \& THOLLANDER, P. 2016. Energy management in industry-a systematic review of previous findings and an integrative conceptual 
International Journal of Social Science and Economic Research

ISSN: 2455-8834

Volume:06, Issue:01 "January 2021"

framework. Journal of Cleaner Production, 112, 3692-3708.

SECK, G. S., GUERASSIMOFF, G. \& MAÏZI, N. 2013. Heat recovery with heat pumps in nonenergy intensive industry: A detailed bottom-up model analysis in the French food \& drink industry. Applied Energy, 111, 489-504.

SMIT, G. 2003. Dairy processing: improving quality, Woodhead Publishing.

SOLA, A. V. \& MOTA, C. M. 2020. Influencing factors on energy management in industries. Journal of Cleaner Production, 248, 119263.

STEINBERGER, J. K., VAN NIEL, J. \& BOURG, D. 2009. Profiting from negawatts: Reducing absolute consumption and emissions through a performance-based energy economy. Energy Policy, 37, 361-370.

TANAKA, K. 2008. Assessment of energy efficiency performance measures in industry and their application for policy. Energy policy, 36, 2887-2902.

THOLLANDER, P., KARLSSON, M., ROHDIN, P., WOLLIN, J. \& ROSENQVIST, J. 2020. Introduction to Industrial Energy Efficiency: Energy Auditing, Energy Management, and Policy Issues, Academic Press.

WANG, L. 2014. Energy efficiency technologies for sustainable food processing. Energy efficiency, 7, 791-810.

WANG, L., TIWARI, B., NORTON, T. \& HOLDEN, N. 2014. Energy consumption and reduction strategies in food processing. Sustainable Food Processing, first ed. Wiley and Sons, Oxford, 377-400.

YAMAN, M. C. 2009. Energy efficiency in a university building: Energy performance assessment of IZTECH administrative building. Izmir Institute of Technology. 